\title{
Geometri dan Pengukuran dalam Permainan Rakyat Kabupaten Sumbawa Barat
}

\author{
Diena Frentika ${ }^{1)^{*}}$, Heru Tri Novi Rizki ${ }^{1)}$ \\ ${ }^{1)}$ Universitas Cordova \\ *dienafrentika@undova.ac.id
}

\begin{abstract}
Abstrak: Penelitian ini bertujuan untuk mengeksplorasi dan mendeskripsikan etnomatematika pada konsep geometri dan pengukuran yang ada dalam permainan rakyat Kabupaten Sumbawa Barat yaitu Barapan Kebo dan Sampo Ayam. Penelitian ini merupakan penelitian eksploratif dengan pendekatan penelitian kualitatif. Penelitian ini dilaksanakan tahun 2020 di Kabupaten Sumbawa Barat. Teknik pengumpulan data yang dilakukan adalah wawancara, observasi, dan studi pustaka. Teknik analisis data yang digunakan yaitu pengumpulan data, reduksi data, display data, dan verifikasi data. Hasil penelitian menunjukkan bahwa terdapat konsep geometri dan pengukuran dalam permainan rakyat Barapan Kebo dan Sampo Ayam. Etnomatematika di dalam Barapan Kebo dan Sampo Ayam yaitu kecepatan, waktu, jarak, sudut, garis, satuan panjang, bangun datar segitiga dan bangun datar segiempat.
\end{abstract}

Kata Kunci: Ethnomathematics, Geometry, Measurement, Traditional Games, West Sumbawa.

\section{Pendahuluan}

Matematika berperan penting untuk melatih keterampilan yang diperlukan pada abad ke-21 yang mengharuskan siswa memiliki banyak keterampilan seperti berpikir kritis, kreatif, komunikatif, dan kolaboratif (Rizki, Frentika, \& Wijaya, 2018). Melalui matematika siswa juga berlatih untuk berargumen secara logis, sistematis, dan dapat dibuktikan kebenarannya (Frentika, Sugiman, \& Rizki, 2020). Pentingnya matematika menjadikan matematika wajib dipelajari di sekolah. Meskipun demikian, tidak semua siswa senang belajar matematika sehingga diperlukan inovasi pembelajaran yang dapat membangun apresiasi siswa terhadap matematika. Apresiasi dipandang sebagai faktor penentu keberhasilan dalam matematika (Ismail, Kasmin, \& Alias, 2005) karena memberikan kekuatan dan motivasi untuk mau belajar dan mencapai kesuksesan (Girod, Rau, \& Schepige, 2003). Dengan adanya antusiasme dan pengetahuan awal maka kesiapan belajar siswa dapat terbentuk (Rizki, Wijaya, \& Frentika, 2020). Adanya keterkaitan dengan pengetahuan awal dapat mempermudah siswa memahami pengetahuan yang baru diajarkan karena belajar merupakan proses aktif untuk menghubungkan konsep baru dengan konsep yang telah dimiliki siswa sebelumnya, aktivitas membangun koneksi pengetahuan yang lalu, sekarang, dan yang akan datang, serta proses yang dipengaruhi oleh bagaimana pembelajaran dilakukan dan efektif tidaknya suatu pembelajaran (Watkins et al., 2000).

Salah satu pembelajaran yang memadukan konsep matematika dan pengetahuan yang dekat dengan kehidupan siswa adalah pembelajaran etnomatematika. Pembelajaran ini merupakan pembelajaran kontekstual yang membawa dunia nyata siswa ke dalam pembelajaran menggunakan konteks budaya setempat (Abi, 2016). Melalui pembelajaran berbasis budaya, siswa memiliki kesempatan untuk belajar berdasarkan pengalamannya sebagai bagian dari masyarakat budaya (Wahyuni, 2015).

Etnomatematika sendiri berasal dari kata 1) "Ethno" yang artinya berhubungan dengan konteks sosial budaya seperti budaya masyarakat, kode perilaku, mitos, symbol, dan lain-lain, 2) "Mathema" yang artinya menjelaskan, mengetahui, melakukan kegiatan seperti pengkodean, mengukur, dan menyimpulkan, dan 3) "Tics" yang berasal dari kata techne yang berarti Teknik (Pratiwi \& Pujiastuti, 2020). Etnomatematika memiliki peran penting untuk menjembatani antara kehidupan nyata berbasis budaya dengan pembelajaran matematika di sekolah (Abi, 2016). Etnomatematika menjelaskan ide-ide matematika yang terkandung dalam suatu budaya 
sehingga tidak hanya membicarakan tentang budaya namun juga hubungan antara matematika dan budaya. Melalui peran etnomatematika dapat tercapai integrasi budaya dalam pembelajaran sehingga konteks belajar siswa menjadi tidak asing dan lebih bermakna.

Integrasi budaya dalam pembelajaran dapat memberikan kejelasan hubungan antara matematika dan penerapannya dalam kehidupan. Hal ini sekaligus sebagai penegasan bagi siswa bahwa matematika yang dipelajari di sekolah relevan dengan matematika yang ada dalam kehidupan sehari-hari. Selain itu, penerapan pembelajaran berbasis budaya juga memiliki keunggulan diantaranya dapat meningkatkan kemampuan pemecahan masalah (Astuningtyas, Wulandari, \& Farahsanti, 2017), menurunkan kecemasan belajar matematika (Ulya \& Rahayu, 2017), memudahkan siswa memahami konsep matematika (Prasetyo, Mastur, \& Asikin, 2019) serta dapat memotivasi dan menstimulasi siswa dalam mengatasi kejenuhan dan kesulitan belajar matematika (Sirate, 2012).

Namun demikian, masyarakat tidak sepenuhnya menyadari peran matematika dalam budaya masyarakat. Matematika dipandang tidak terkait dengan budaya padahal filosofi matematika ditujukan untuk berkontribusi pada budaya dan perkembangan mental serta mentransfer pengetahuan yang berguna dalam kehidupan (Pratiwi \& Pujiastuti, 2020). Di dalam budaya masyarakat terkandung ide-ide matematika dan melalui budaya siswa dapat belajar matematika. Budaya dan pendidikan memiliki hubungan yang erat sehingga melalui etnomatematika dapat diwujudkan pembelajaran yang memadukan konsep budaya dalam aktivitas belajar matematika.

Kabupaten Sumbawa Barat merupakan salah satu daerah yang belum mengoptimalkan kekayaan budaya dan potensi yang dimilikinya untuk menunjang keberhasilan pembelajaran matematika. Padahal Kabupaten Sumbawa Barat memiliki potensi sumberdaya alam yang melimpah terutama pada sektor pariwisata dan budaya (Ariani \& Nursan, 2017). Masyarakat Kabupaten Sumbawa Barat masih menjaga kebiasaan tradisional dalam bertani, berburu, dan beternak serta melestarikan budaya permainan rakyat seperti Barapan Kebo (Balapan Kerbau) dan Barapan Ayam atau Sampo Ayam (Balapan Ayam) (Ariani \& Nursan, 2017). Selain sebagai sarana bersilahturahim di antara sesama pecinta Barapan Kebo dan di antara sesama pecinta Sampo Ayam, permainan rakyat ini juga memiliki potensi sebagai objek wisata budaya unggulan masyarakat Kabupaten Sumbawa Barat. Melalui permainan rakyat tradisional, seseorang dapat belajar bersosialisasi, berkomunikasi, berpikir, dan berhitung dengan cara yang menyenangkan. Permainan tradisional tidak hanya mengandung unsur kesenangan tetapi juga mengandung nilai-nilai budaya dan dapat melatih kecakapan anak untuk berpikir dan berhitung (Pratiwi \& Pujiastuti, 2020).

Salah satu materi matematika yang terkandung dalam permainan rakyat yaitu geometri dan pengukuran (Aini et al., 2019; Pratiwi dan Pujiastuti, 2020). Geometri merupakan jaringan interkoneksi yang membutuhkan representasi dan penalaran sehingga konseptualisasi dan analisis tidak hanya sebatas tampilan fisik namun sampai pada membayangkan secara spasial (Alex \& Mammen, 2012) yang diajarkan bertahap mulai dari tahap konkret menuju tahap abstrak (Rizki, Wijaya \& Frentika, 2018). Geometri memberikan peluang untuk membuat siswa berpikir secara aktif, melakukan senam otak dan mengembangkan keterampilan menyelesaikan masalah serta membuat perbandingan dan generalisasi (Bal, 2011). Guna mendapatkan informasi tentang konsep Geometri dan Pengukuran yang ada pada permainan rakyat Kabupaten Sumbawa Barat, perlu dilakukan eksplorasi Etnomatematika dalam Barapan Kebo dan Sampo Ayam. Dengan diperolehnya kejelasan hubungan kearifan local dengan pembelajaran matematika, harapannya dapat menjadi sumber acuan guru untuk mengembangkan proses pembelajaran maupun bahan ajar berbasis permainan rakyat sehingga dapat menumbuhkan rasa cinta pada budaya dan matematika melalui permainan rakyat.

\section{Metode}

Penelitian ini menggunakan pendekatan kualitatif dengan fokus kajian konsep matematika dalam permainan rakyat Barapan Kebo dan Barapan Ayam. Penelitian ini termasuk penelitian eksploratif (narrative) karena peneliti melakukan eksplorasi terhadap permainan rakyat Kabupaten Sumbawa Barat. Penelitian eksploratif fokus mempelajari seseorang, mengumpulkan data melalui kumpulan cerita, menyampaikan pengalaman individu dan membahas makna dari pengalaman-pengalaman (Creswell, 2012). Adapun metode penelitiannya menggunakan penelitian etnografi karena untuk menggambarkan, menjelaskan, dan menganalisis unsur kebudayaan masyarakat. 
Penelitian ini dilakukan di Kabupaten Sumbawa Barat pada tahun 2020. Penelitian ini diawali dengan studi pendahuluan untuk menentukan masalah, tujuan, dan urgensi penelitian. Dari hasil studi pendahuluan, peneliti merancang metode penelitian untuk dapat menjawab masalah penelitian yang dirumuskan. Peneliti selanjutnya melakukan pengumpulkan data dan analisis data untuk menghasilkan kesimpulan yang tepat. Proses pengumpulan data dan analisis data dilakukan secara terus menerus dan beriringan hingga diperoleh data pendukung yang mendasari penarikan kesimpulan penelitian.

Jenis data dalam penelitian ini adalah data kualitatif sehingga peneliti berperan sebagai instrumen utama pengumpulan data. Teknik pengumpulan data yang digunakan dalam penelitian ini adalah wawancara, observasi, dan studi pustaka. Observasi pada permainan rakyat Barapan Kebo dilaksanakan di lapangan Bentiu Kecamatan Taliwang dan lokasi Barapan Kebo di Desa Sapugara Bree Kecamatan Brang Rea sedangkan observasi pada permainan rakyat Sampo Ayam dilaksanakan di lokasi Sampo Ayam di Desa Tamekan, Kecamatan Taliwang. Adapun narasumber wawancara dalam penelitian ini adalah ketua Lembaga Adat Tana Samawa (LATS), ketua komunitas Barapan Kebo dan ketua komunitas Sampo Ayam.

Teknik analisis data yang digunakan dalam penelitian ini mengikuti pola analisis Miles dan Huberman terdiri dari 4 tahap yaitu pengumpulan, reduksi, display, dan verifikasi/penyimpulan (Milles dan Huberman, 1992). Pengumpulan data juga termasuk tahapan analisis data sehingga tahap pengumpulan data dan analisis data dilakukan secara bersamaan dan berkelanjutan. Setelah data penelitian dikumpulkan, peneliti melakukan reduksi data. Tahap reduksi data dilakukan sebagai proses terus menerus untuk memilih, memusatkan, mentransformasi, dan mengelompokkan data sesuai masalah penelitian untuk mempertajam dan mengorganisir data lapangan. Data yang telah direduksi kemudian disajikan secara deskriptif untuk memudahkan penafsiran data dan penarikan kesimpulan. Peneliti kemudian menarik kesimpulan berdasarkan data-data yang diperoleh sehingga dihasilkan temuan etnomatematika dalam Barapan Kebo dan Sampo Ayam sebagai permainan rakyat Kabupaten Sumbawa Barat.

\section{Hasil dan Pembahasan}

Barapan Kebo dan Sampo Ayam merupakan permainan rakyat Kabupaten Sumbawa Barat yang telah mengalami proses pengembangan (Amir et al., 2017). Barapan dimaknai sebagai berkejaran atau menghalau dengan kecepatan dan sampo dimaknai sebagai balapan. Dengan demikian Barapan Kebo dan Sampo Ayam merupakan permainan rakyat Kabupaten Sumbawa Barat yang dilakukan dengan mengadu kecepatan lari kerbau ataupun ayam. Permainan Barapan Kebo dan Sampo Ayam dapat dilihat pada Gambar di bawah ini.
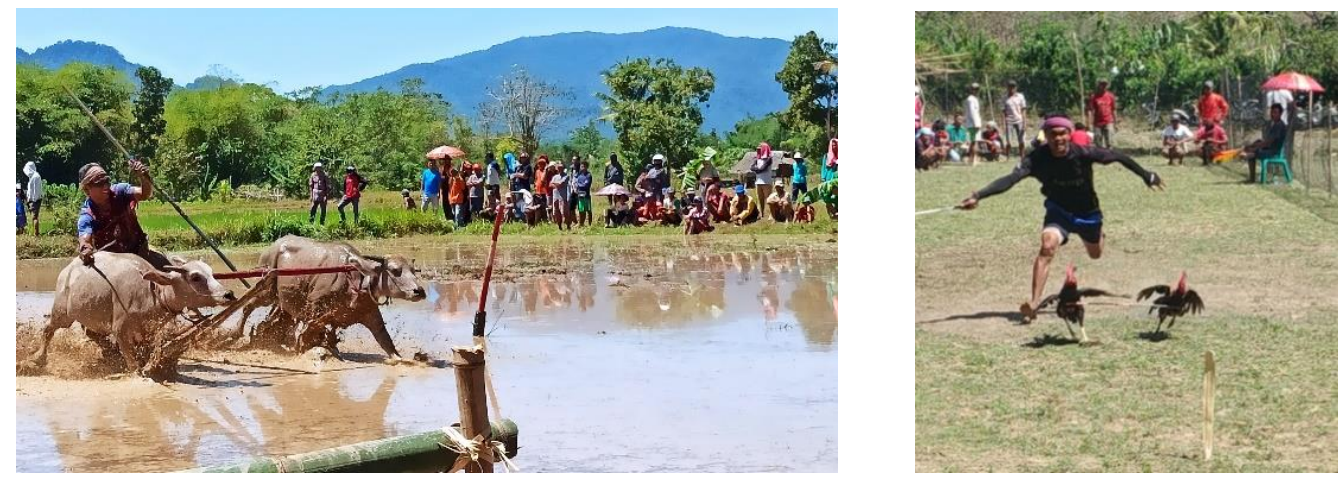

Gambar 1. Barapan Kebo (kiri) dan Sampo Ayam (kanan)

(Sumber: Dokumen pribadi)

\section{Barapan Kebo}

Barapan Kebo awalnya dilakukan menjelang musim tanam padi dengan membawa kerbau-kerbau ke dalam sawah untuk mengolah tanah pertanian sebelum mengenal alat bercocok tanam. Selanjutnya muncul ide untuk menunggang sepasang kerbau yang diikat dengan Noga dan seorang joki yang menunggangi sepasang kerbau dengan berdiri di atas kayu berbentuk segitiga yang disebut kareng (Amir et al., 2017). Ide tersebut berkembang kembali menjadi kegemaran mengadu kecepatan lari kerbau untuk memperoleh hadiah bagi sepasang kerbau yang berlari paling cepat dan menyentuh saka (tiang) dengan noganya. 
Tabel 1. Pelengkapan Barapan Kebo

\begin{tabular}{cl}
\hline No & \multicolumn{1}{c}{ Nama dan Keterangan } \\
\hline 1 & $\begin{array}{l}\text { Kerbau } \\
\text { Kerbau yang digunakan adalah sepasang kerbau jantan yang dihias } \\
\text { dengan pernak-pernik. }\end{array}$ \\
2 & $\begin{array}{l}\text { Arena } \\
\text { Arena Barapan Kebo adalah arena berlumpur dengan estimasi panjang } \\
\text { lintasan lari } 85-100 \text { meter dan lebar } 8 \text { meter. }\end{array}$ \\
3 & $\begin{array}{l}\text { Noga } \\
\text { Noga adalah kayu untuk menyatukan sepasang kerbau. }\end{array}$ \\
$4 \quad$ & $\begin{array}{l}\text { Kareng } \\
\text { Kareng adalah tempat berdiri atau pijakan joki untuk mengarahkan lari } \\
\text { kerbau yang terbuat dari kayu disusun berbentuk segitiga. }\end{array}$
\end{tabular}

5 Mangkar

Mangkar adalah pelecut yang digunakan untuk memacu lari kerbau dengan estimasi panjang mangkar 50-100 meter yang disesuaikan dengan kenyamanan sang joki dalam menggunakannya.

6 Saka

Saka adalah kayu pancang yang diletakkan di garis finish. Setiap pasang kerbau harus menyentuh saka dengan noganya.

7 Joki

Joki adalah orang yang bertugas naik ke atas kareng dan mengarahkan kerbau menggunakan mangkar untuk berlari secepat mungkin dan mengenai saka.

8 Sandro

Sandro adalah sebutan untuk orang sakti dengan ilmu supranatural menurut masyarakat Sumbawa. Terdapat 2 jenis Sandro yaitu:

a) Sandro Saka yang bertugas menjaga saka mulai dari sebelum hingga selesai perlombaan,

b) Sandro Kebo yang bertugas untuk membantu kemenangan sang kerbau dengan bacaan dan ramuan untuk memperjelas pandangan dan meningkatkan stamina sang kerbau.

9 Pencatat waktu

Pencatat waktu (stopwatch) digunakan untuk menghitung lama waktu berlarinya kerbau untuk mencapai garis finish.

10 Bendera

Terdapat 2 bendera yang digunakan yaitu bendera start dan bendera finish sebagai tanda petugas pencatat waktu untuk memulai dan mengakhiri pencatatan waktu lari kerbau.

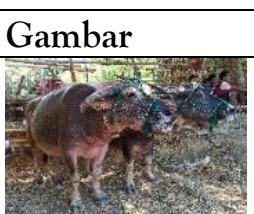

Sumber: dokumen pribadi

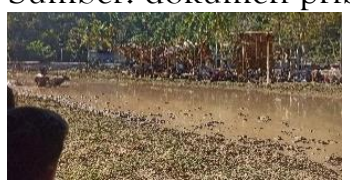

Sumber: dokumen pribadi

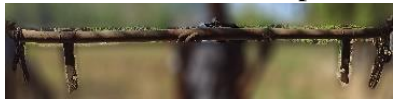

Sumber: dokumen pribadi

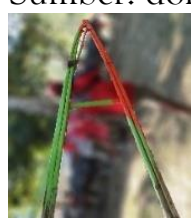

Sumber: dokumen pribadi

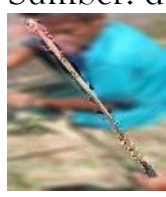

Sumber: dokumen pribadi

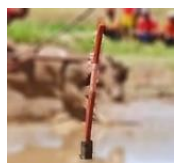

Sumber: dokumen pribadi

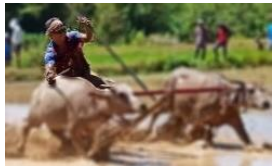

Sumber: dokumen pribadi

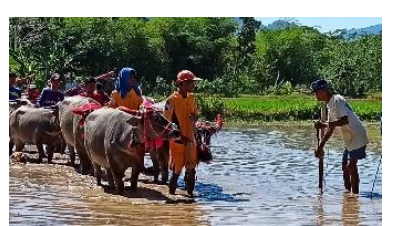

Sumber: dokumen pribadi

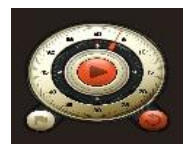

Sumber: dokumen pribadi

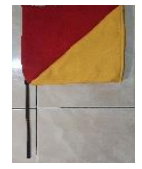

Sumber: dokumen pribadi

Dalam Barapan Kebo terdapat 8 pengelompokkan kelas kerbau berdasarkan usia yaitu kelas A, B, C, D, E, F, G, dan $\mathrm{H}$ atau kelas 1, 2, 3, 4, 5, 6, 7, dan 8. Tahapan lari dalam barapan kerbau terdiri dari 4 jenis yaitu 1) lari bintang merupakan babak penyisihan semua kerbau, 2) lari harapan merupakan lari untuk pasangan kerbau 
yang belum lolos pada lari bintang, 3) lari umum merupakan lari untuk pasangan kerbau yang mendapat juara pada lari bintang dan lari harapan dan 4) lari favorit merupakan lari untuk semua pasangan kerbau yang juara di setiap kelas untuk memperebutkan hadiah yang lebih besar (Amir et al., 2017). Dalam permainan rakyat Barapan Kebo terdapat istilah-istilah sebagaimana disajikan pada tabel 1.

Tabel 2. Pelengkapan Sampo Ayam

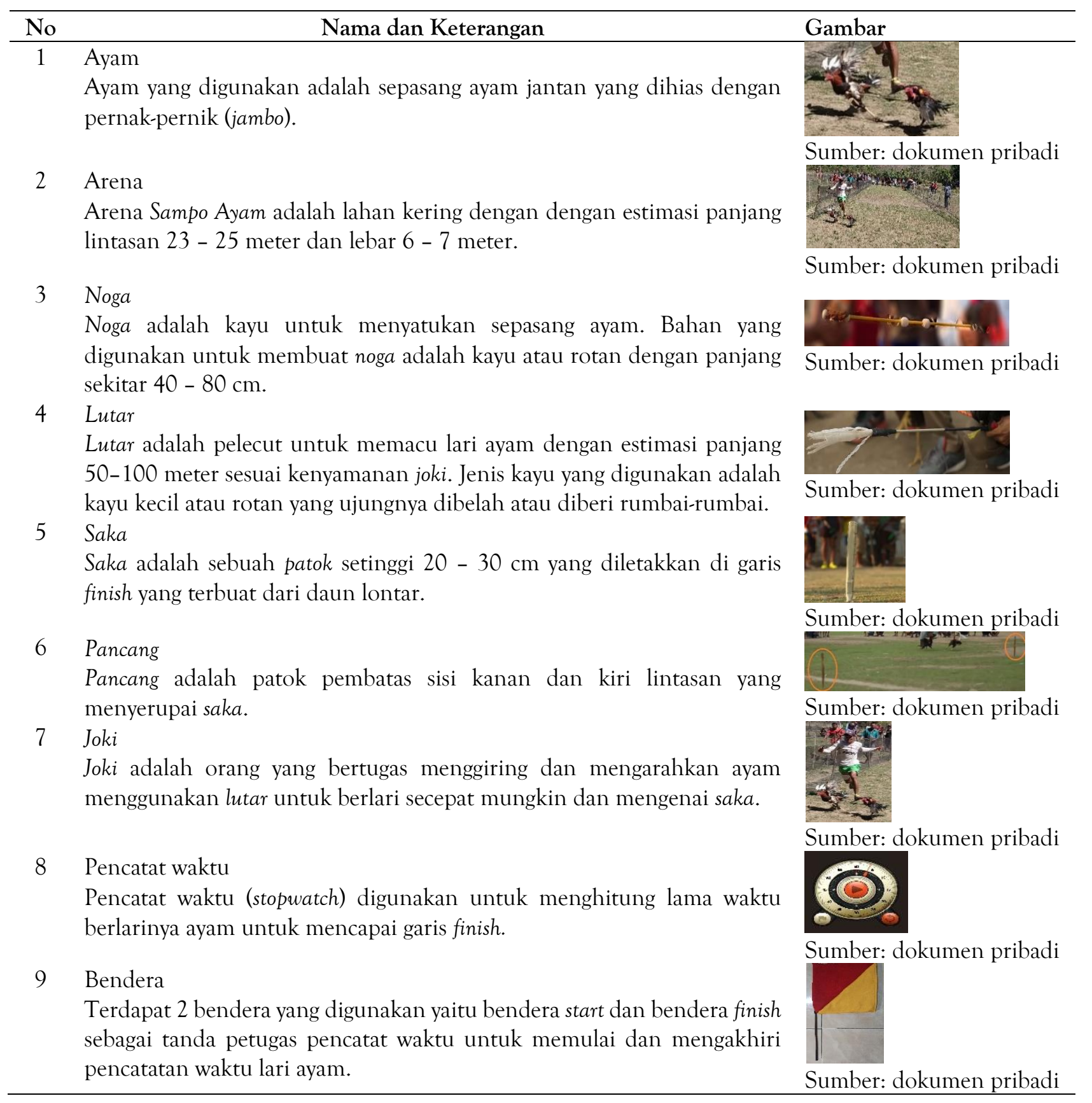

\section{Sampo Ayam}

Sampo Ayam dulunya dilakukan oleh anak-anak yang menghabiskan waktu bermain mengejar ayam. Saat ini Sampo Ayam tidak saja menjadi ajang bermain anak-anak namun sudah menjadi ajang perlombaan bagi lelaki dewasa dalam mengadu kecepatan berlari ayamnya. Sebagaimana Barapan Kebo, Sampo Ayam melibatkan sepasang ayam yang diikat dengan Noga. Hal yang membedakannya adalah seorang joki Barapan Kebo naik ke atas kareng untuk mengarahkan larinya kerbau sedangkan joki Sampo Ayam berlari di belakang ayam dengan membawa lutar untuk menggiring dan menghalau ayam agar berlari cepat dan menyentuh saka dengan noganya.

Dalam Sampo Ayam terdapat 6 pengelompokkan kelas ayam berdasarkan usia yaitu A, B, C, D, E, dan F atau 1, 2, 3, 4, 5, dan 6. Sebagaimana Barapan Kebo, tahapan lari dalam Sampo Ayam juga terdiri dari 4 jenis yaitu 
lari bintang, lari harapan, lari umum dan lari favorit. Namun demikian banyaknya lari dan banyaknya kelas di setiap penyelenggaraan Barapan Kebo maupun Sampo Ayam dapat mengalami perubahan sesuai dengan kesepakatan panitia dan peserta serta banyaknya hadiah yang diperebutkan. Dalam permainan rakyat Sampo Ayam terdapat istilah-istilah sebagaimana disajikan pada tabel 2.

Permainan rakyat Barapan Kebo dan Sampo Ayam selain sebagai hiburan masyarakat juga mengajarkan berbagai karakter positif yaitu 1) Sikap kompetitif untuk selalu berusaha mencapai kesuksesan dan kemenangan, 2) Teori keseimbangan melalui keseimbangan lari dan ukuran kerbau atau ayam kanan dan kiri, 3) Mengambil keputusan terbaik dengan cepat yang diajarkan melalui pengambilan keputusan joki untuk mengarahkan kerbau maupun ayam harus belok ke kanan atau kiri sehingga dapat mencapai target yang ditetapkan, 4) Sikap kejujuran yang diajarkan melalui kejujuran juri penentu waktu dalam menyebutkan waktu lari kerbau atau ayam, 5) Sikap toleransi dan saling menghormati yang diajarkan melalui budaya antri kerbau atau ayam sebelum mulai berlari, 6) Sikap untuk menjaga silahturahim dan kekeluargaan yang diajarkan melalui kesepakatan masyarakat Kabupaten Sumbawa Barat dengan Kabupaten Sumbawa untuk melaksanakan kegiatan Barapan Kebo dan Sampo Ayam secara bergiliran sehingga memberikan kesempatan untuk saling mengunjungi daerah antar Kabupaten di desa-desa yang berbeda, dan sikap-sikap lainnya. Selain mengandung nilai karakter, Barapan Kebo dan Sampo Ayam juga mengandung unsur etnomatematika dalam konsep geometri dan pengukuran sebagaimana disajikan pada tabel 3 .

Tabel 3. Unsur Etnomatematika dalam Barapan Kebo dan Sampo Ayam

\begin{tabular}{|c|c|c|}
\hline No & Bagian & Penjelasan Etnomatematika \\
\hline 1 & Kareng & $\begin{array}{l}\text { Pada kareng terdapat pola segitiga dan sudut sehingga berkaitan dengan } \\
\text { beberapa konsep seperti: } \\
\text { a. panjang sisi dan keliling segitiga } \\
\text { b. besar sudut pada segitiga }\left(\angle A+\angle B+\angle C=180^{\circ}\right) \\
\text { c. sudut lancip dan sudut tumpul } \\
\text { d. garis berpelurus }\end{array}$ \\
\hline 2 & Noga & $\begin{array}{l}\text { Pada Noga terdapat pola sudut dan ruas garis sehingga berkaitan dengan } \\
\text { konsep sudut siku-siku, titik tengah ruas garis, dan jarak antara } 2 \text { titik. }\end{array}$ \\
\hline 3 & $\begin{array}{l}\text { Mangkar, } \\
\text { lutar, dan } \\
\text { saka }\end{array}$ & $\begin{array}{l}\text { Pada mangkar, lutar, dan saka terdapat pola ruas garis sehingga } \\
\text { berkaitan dengan konsep garis lurus dan konversi satuan panjang }\end{array}$ \\
\hline 4 & $\begin{array}{l}\text { Lari } \\
\text { kerbau }\end{array}$ & $\begin{array}{l}\text { Pada kegiatan lari kerbau mengandung konsep kecepatan, jarak } \\
\text { tempuh, waktu tempuh, serta konversi waktu (jam, menit, detik) }\end{array}$ \\
\hline 5 & $\begin{array}{l}\text { Arena } \\
\text { lomba }\end{array}$ & $\begin{array}{l}\text { Arena Barapan Kebo dan Sampo Ayam mengandung konsep bangun } \\
\text { datar segi empat yaitu persegi panjang sehingga berkaitan dengan } \\
\text { materi panjang sisi, keliling, dan luas daerah persegi panjang. }\end{array}$ \\
\hline 6 & Pancang & $\begin{array}{l}\text { Pancang dan saka pada Sampo Ayam memiliki bentuk yang sama yaitu } \\
\text { pola ruas garis. Akan tetapi titik yang dibentuk oleh kedua pancang } \\
\text { (kanan dan kiri) dan saka dapat membentuk pola segitiga sama kaki } \\
\text { sehingga berkaitan dengan konsep panjang sisi, keliling, dan luas } \\
\text { daerah segitiga sama kaki serta sudut-sudut pada segitiga sama kaki. }\end{array}$ \\
\hline
\end{tabular}

Berdasarkan Tabel 3 di atas dapat diketahui bahwa permainan Barapan Kebo dan Sampo Ayam mengandung banyak konsep geometri dan pengukuran yang dapat digunakan dalam pembelajaran matematika. Jika guru menerapkan pembelajaran berbasis budaya menggunakan etnomatematika sebagaimana tersaji dalam Tabel 3, maka dapat mengajarkan pada siswa bahwa budaya yang mereka miliki mengandung nilai-nilai matematika dan siswa dapat belajar matematika melalui budaya. Dengan demikian terjadi perpaduan antara budaya dan pendidikan dalam suatu proses pembelajaran yang tidak hanya mengajarkan siswa untuk mencapai standar kompetensi matematika tertentu namun juga memupuk rasa cinta budaya dalam diri siswa. Harapannya, pembelajaran berbasis budaya bisa berkontribusi pada pemeliharaan budaya dari generasi ke generasi sehingga budaya masyarakat tetap ada dan dikenal. 
Hasil penelitian ini memberikan dukungan terhadap penelitian sebelumnya bahwa permainan rakyat mengandung konsep matematika yang dapat diterapkan dalam pembelajaran matematika yang lebih kontekstual. Hasil penelitian pada permainan rakyat Kampung Naga menunjukkan bahwa dalam pemainan congklak mengandung konsep operasi hitung dan modulo, dalam permainan galah mengandung konsep peluang, pengurangan, dan penjumlahan, dan dalam [ermainan pecle mengandung konsep geometri,simetri lipat, dan jaring-jaring bangun (Muzdalipah \& Yulianto, 2015. Hasil penelitian pada permainan rakyat Melayu Sambas menjelaskan adanya konsep bilangan bulat, jarak, waktu, peluang, membilang bilangan bulat, himpunan, bangun datar, pengukuran, operasi bilangan bulat, kesimetrisan, serta barisan dan deret (Safitri, Hartoyo, \& Nursangaji, 2015). Dalam permainan rakyat kelereng juga ditemukan adanya konsep bola, lingkaran, dan jarak (Pratiwi \& Pujiastuti, 2020) yang diterapkan dalam pembelajaran mampu meningkatkan aktvitas guru, aktivitas siswa, dan pemahaman konsep perkalian siswa (Mei, Seto \& Wondo, 2020). Dengan demikian, permainan rakyat dan matematika memiliki keterkaitan satu sama lain yang dapat saling melengkapi. Selain itu, permainan rakyat juga dapat diterapkan dalam pembelajaran matematika untuk mempelajari kompetensi dan pola berpikir matematis sekaligus sebagai upaya pelestarian budaya.

\section{Simpulan}

Berdasarkan uraian di atas, dapat disimpulkan bahwa terdapat unsur-unsur etnomatematika terkait konsep geometri dan pengukuran yang terkandung di dalam budaya Barapan Kebo dan Sampo Ayam sebagai permainan rakyat Kabupaten Sumbawa Barat. Hasil penelitian menunjukkan adanya konsep geometri dan pengukuran seperti kecepatan, waktu dan jarak tempuh, sudut, konsep satuan panjang dan konsep bangun datar segitiga dan segiempat yang dapat diterapkan dalam pembelajaran matematika. Untuk memperluas kajian, hasil penelitian ini dapat dikembangkan ke dalam penerapan pembelajaran guna mengetahui implikasi penerapan etnomatematika terhadap suatu variable tertentu serta dikembangkan menjadi bahan ajar yang dapat diterapkan dalam pembelajaran matematika.

\section{Ucapan Terima Kasih}

Penulis mengucapkan terima kasih kepada Ketua Lembaga Adat tana Samawa, Ketua Komunitas Barapan Kebo dan Ketua Komunitas Sampo Ayam Kabupaten Sumbawa Barat yang telah membantu kelancaran penelitian ini.

\section{Daftar Pustaka}

Abi, A. M. (2016). Integrasi etnomatematika dalam kurikulum matematika sekolah. JPMI (Jurnal Pendidikan Matematika Indonesia), 1(1), 1-6. http://dx.doi.org/10.26737/jpmi.v1i1.75

Aini, Z., Afifah, N., Muslim, I., \& Hasanah, S. I. (2019). Etnomatematika: eksplorasi budaya kerabhen sape madura. Journal of Medives: Journal of Mathematics Education IKIP Veteran Semarang, 3(2), 177-183.

Alex, J. K., \& Mammen, K. J. (2012). A survey of South African grade 10 learners' geometric thinking levels in terms of the Van Hiele theory. Anthropologist, 14(2), 123-129. https://doi.org/10.1080/09720073.2012.11891229

Amir, L., Suharti, Sartika, D., Aini, F., Ibrahim, dan Budianto. (2017). Sejarah Permainan Rakyat Sumbawa Barat. Taliwang: Ssatera Institute.

Ariani, Z. dan Nursan, M. (2017). Strategi pengembangan desa mantar sebagai kawasan desa wisata di kabupaten Sumbawa Barat. Jurnal Biologi Tropis, 17(2), 58-68. DOI: http://dx.doi.org/10.29303/jbt.v17i2.407

Astuningtyas, E. L., Wulandari, A. A., dan Farahsanti, I. (2017). Etnomatematika dan pemecahan masalah kombinatorik. Jurnal Math Educator Nusantara: Wahana Publikasi Karya Tulis Ilmiah di Bidang Pendidikan Matematika, 3(2), 111-118. DOI: https://doi.org/10.29407/jmen.v3i2.907

Bal, A. P. (2011). Geometry thinking levels and attitudes of elementary teacher candidates. Inonu University Journal of the Faculty of Education, 12(3), 97-115.

Creswell, J.W. (2012). Educational Research: Planning, Conducting, and Evaluating Quantitative and Qualitative Research (4 ${ }^{\text {th }}$ Ed). Boston: Pearson 
Girod, M., Rau, C., \& Schepige, A. (2003). Appreciating the beauty of science ideas: teaching for aesthetic understanding. Science education, 87(4): 574-587. https://doi.org/10.1002/sce.1054

Frentika, D., Sugiman, dan Rizki, H.T.N. (2020). Kemampuan membuktikan mahasiswa calon guru matematika. Axiom: Jurnal Pendidikan dan Matematika. 9(1): 51-63. http://dx.doi.org/10.30821/axiom.v9i1.7236

Ismail, Z., Kasmin, M.K, \& Alias, N. (2005).The mathematics carnival: A platform to appreciate mathematics. The Mathematics Education into the $21^{\text {st }}$ Century Project Universiti Teknologi Malaysia. (115-118)

Jati, S.P., Mastur, Z., dan Asikin, M. (2019). Potensi etnomatematika untuk mengembangkan kemampuan komunikasi matematis. PRISMA, Prosiding Seminar Nasional Matematika UNNES, hal 277-286

Mei, M.F., Seto, S.B., dan Wondo, M.T.S. (2020). Pembelajaran kontekstual melalui permainan kelereng pada siswa kelas III SD untuk meningkatkan pemahaman konsep perkalian. JUPIKA: Jurnal Pendidikan Matematika Universitas Flores, 3(2), 61-70. https://doi.org/10.37478/jupika.v3i2.669

Milles dan Huberman. (1992). Analisis Data Kualitatif. Jakarta: Universitas Indonesia Press.

Muzdalipah, I. dan Yulianto, E. (2015). Pengembangan desain pembelajaran matematika untuk siswa SD berbasis aktivitas budaya dan permainan tradisional masyarakat kampung naga. Jurnal Siliwangi, 1(1), 63-74.

Pratiwi, J.W. dan Pujiastuti, H. (2020). Eksplorasi Etnomatematika pada Permainan Tradisional kelerang. Jurnal Pendidikan Matematika Raflesia, 5(2), 1-12. DOI: https://doi.org/10.33449/jpmr.v5i2.11405

Rizki, H.T.N., Frentika, D, dan Wijaya, A. (2018). Exploring students' adaptive reasoning skills and van hiele levels of geometric thinking: a case study in geometry. IOP Conference Series: Journal of Physics: Conference Series. 983 (1), 1-7. DOI: $10.1088 / 1742-6596 / 983 / 1 / 012148$

Rizki, H.T.N., Wijaya, A., dan Frentika, D. (2020). Pengembangan perangkat pembelajaran dengan pendekatan Knisley berorientasi pada level berpikie Van Hiele dan kemampuan penalaran adaptif. Axiom: Jurnal Pendidikan dan Matematika. 9(1): 64-79. DOI: http://dx.doi.org/10.30821/axiom.v9i1.7237

Safitri, D., Hartoyo, A., dan Nursangaji, A. (2015). Eksplorasi konsep matematika pada permainan masyarakat melayu sambas. Jurnal Pendidikan dan Pembelajaran Untan, 4(6), 1-12

Sirate, F.S. (2012). Implementasi etnomatematika dalam pembelajaran matematika pada jenjang pendidikan sekolah dasar. Lentera Pendidikan, 15(1): 41-54

Ulya, H dan Rahayu, R. (2017). Pembelajaran etnomatematika untuk menurunkan kecemasan matematika. Jurnal Mercumatika: Jurnal Penelitian Matematika dan Pendidikan Matematika,2(1), 16-23. DOI: https://doi.org/10.26486/jm.v2i2.295

Wahyuni, I. (2015). Eksplorasi Etnomatematika Masyarakat Sidoarjo. Fenomena (Jurnal Penelitian Islam Indonesia), 15(2), 225-238

Watkins, C., Carnell, E., \& Lodge, C. (2007). Effective learning in classrooms. London: Paul Chapman Publishing 